\title{
Role of Sadhyovamana as Emergency Procedure in Panchakarma: A Review
}

\author{
Review Article
}

\section{Lodha Sheetal G1, Karade Ruchika $\mathbf{S}^{2 *}$}

\author{
1. Assistant Professor, 2. P.G Scholar, \\ Department of Panchakarma, R. A. Podar Medical Ayurved College Mumbai.
}

\begin{abstract}
Over the last few decades, common people have a belief that Ayurveda can treat only chronic diseases. In the acute condition, we generally preferred modern medicine. But in that era also, a description of acute diseases suggested the availability of emergency treatment. Panchakarma chikitsa plays a vital role in ayurvedic treatment line, but in emergency cases, due to lack of time, it is not possible to carry out purvakarma, pradhankarma, and pashchat karma of vamana, virechana procedures. In such a condition concept of sadyovamana can be used as emergency treatment. So, to describe the procedure and importance of sadyovamana in comparison with classical vamana procedure critical analysis of literature has been done. It was found that sadyovamana can be used in various atyayika conditions of diseases. In an emergency, as purvakarma is not mandatory to carry out sadyovamana. This procedure can be conducted in a single day. There is no requirement of vishram kala (gap period). Even consideration of kala (time) does not matter many more. It is cost-effective, less time consuming and has an immediate effect, but it lasts for a short period. So, we can use the sadyovamana in the case of atyayika chikitsa of various diseases whenever classical vamana is not possible.
\end{abstract}

Key Words: Atyayika chikitsa, Ayurveda, Panchakarma, Sadyovamana.

\section{Introduction}

Over the last few decades, common people have a belief that Ayurveda can treat only chronic diseases. In the acute condition, we generally preferred modern medicine. But in that era also, a description of acute (ashukari) diseases suggests the availability of emergency treatment. Ayurveda describes the two different methods of treating disease shodhana and shamana (pacification of dosha). Shodhana means detoxification and cleansing of the body. Detoxification of the body done with panchakarma procedures. Panchakarma term indicates the five procedures of shodhana of body channels. These five procedures are vamana (therapeutic emesis) performed to vomit the aggravated kapha dosha. Virechana (purgation) is performed to expelled out aggravated pitta. Nasya (nasal oleation) is carried out to clean channels of the head, neck region mainly. Basti (herbal enema) is the most important procedure, also known as ardha chikitsa (half treatment) of whole Ayurveda, performed to manifest the vitiated vata dosha of the body. Raktamokshana (blood-letting) is performed to treat blood impurity (rakta dushti). These five procedures play a vital role in Ayurveda, treatment of person but

\section{* Corresponding Author:}

\section{Karade Ruchika S}

PG scholar

Department of Panchakarma,

R. A. Podar Medical Ayurved College,

Mumbai. Maharashtra. India

Email Id: ruchikakarade1@gmail.com need some time to carry out. Each procedure requires purvakarma (pre-procedure), pradhan karma (main procedure), and pashchat karma (post-procedure) so need in time. But if there are emergency arises, on the spot we can't perform classical vamana, virechaana, in such condition there is a provision of sadyovamana instead of classical vamana.

The word sadyovamana is a combination of two words sadyo and vamana. According to Shabdkalpadruma, sadya means on the same day, in the very moment, or immediately. According to Amarkosha the meaning of these two words is instantly or at once.

Sadyovamana means to attain an immediate or quick elimination of vitiated doshas through the oral route. It is the instant therapeutic emesis (purificatory procedure) conducted without internal oleation (abhyantara snehapana) and sudation (sweda) in aggravated kapha conditions. In an emergency (atyayik chikitsa) when doshas are in aggravated (utklishta) stage, instead of classical vamana karma, sadyovamana can be given irrespective of kala. This procedure is less time consuming, cost-effective, and beneficial in acute conditions. So, the objective of this review is to describe the meaning and purpose of sadyovamana procedures as an emergency treatment.

\section{Aim and Objectives}

- To highlight the concept of sadyovamana used in an emergency (atyayika chikitsa).

- To describe the procedure of sadyovamana.

\section{Review of Literature}

Ayurveda describes the use of sadyovamana in various diseases. The term sadyo vamana is not directly 
described in compendia but we find the traces of these in various classical texts. In Charak Samhita, Acharya has described the procedure of sadyovamana in jwara chikitsa. Jwara (fever)is dominated by kapha and is located in aamashaya in the stage of utklesha (aggravated). It should be removed by the administration of vamana therapy(1). In Vangasen Jwara chikitsa, it is mentioned that in the case of aamjwara, jwara caused due to ama (toxins), soon after the ingestion of food causes amajwara. Sadyovamana can be given in such a situation. In the case of amajwara, vamana should be given with lawanambu(2) (saltwater). In Pittaj jwara patients with excessive thirst should be given plenty of water and honey for vamana(3).

In Shwasa samprapti, strotas involved is pranvaha stotas. Obstruction in strotas is due to kapha. As there is an utklesha of kapha dosha, sadyovamana can be given(4). Chakrapani in his commentary says that swasa is pitta sthana samudbhava, which refers to the involvement of the pitta with urdhwasthana, through kapha, and vata is responsible for initiating the disease. In the same commentary it is said that pittasthana can be taken as aamashaya. As there is involvement of the utklishta kapha and the disease is aamashaya samudbhava, sadyovaman can be given(5). Vaman brings strotoshudhi and kaphavarodha will be removed(6). Madatyaya is caused due to excessive consumption of madya. Due to teekshna, ushna and ruksha property of madya, utklesha of the kapha- pitta occurs. In Madatyaya patient should take ikshu rasa and madya till his throat (akantha pana) and then made to vomit immediately(7). In the case of Visha, in an emergency (atyayik) condition needs immediate care. Vamana indicated in the visha vegas need not require snehapana or swedana. Hence here we can probably say that the sadyo vamana is mentioned. Acharya Charaka has mentioned vamana in the sthavara visha chikitsa (8). In Gara visha chikitsa, Chakrapani advised giving vamana immediately(9). There is no other treatment better than vamana in case of sthavara visha chikitsa. In Chhardi vyadhi, nidanasevana leads to prakopa of vata. Vata gets located in udara which produces utkleshana of undigested particle. Expels these through the koshtha and agnibala is reduced(10). In Chhardi, agni is in mandavastha, it may not be able to digest the medicine also. Vamana may bring up the utklishta dosha, then undigested substances located in the aamashaya along with the vamana aushadha. Moreover, pravruddha kapha will act like shalya if not expelled outside, so here sadyo vamana can be carried out because usage of snehana, swedana will further worsen the condition of dosha is in aamashaya and pravruddha avastha. In Madhav Nidan, Acharya explained in Kotha chikitsa that, kotha is a disease that arises due to the improper administration of the shodhana chikitsa or due to avastha of pitta, kapha and anna(11). Acharya Vangsena has mentioned vamana should be induced very quickly. He suggested sadyo vamana in kotha by patolanimbavasa kwatha(12). In Alasaka disease utklishta dosha is present. Hence there is no need to produce the utklisha of doshas further so sadyovamana can be performed. In Charak Vimansthana, acharya has mentioned the disease called Amavisha. In amavisha condition emergency treatment should be given (its mentioned as ashukaryitya virudhopakrama cha). In samadosha conditions, made to vomit with lukewarm water with salt followed by sweda(13). Visuchika is a condition that occurs in ajeerna which is characterized by pain which is similar to pricking pain(14). In Vangsena Ajeerna chikitsa, it is described that vamana should be done with lukewarm salt water(15). While performing virechana even after attaining the suddhi lakshana, the medicines remain in the koshtha. Acharya Charaka has advised performing the vamana to bring out excess medicine from the koshtha(16). According to Acharya Sushruta, Sadyovamana can be given to those persons who affiliated with kapha, persons suffering from Ajeerna, and Visha. Acharya Sushruta has mentioned that conditions, where medicine administered for vamana and virechana, does not produce the desired results. Thereby resides in the koshtha and causing the obstructing of the dosha. In such conditions associated with trishna, shula, chhardi etc vamana has to be induced by ushna jala(17)(warm water). Vangasena has described the disease upadamsha that, the excessive of dosha in upadamsha should be expelled out by both routes immediately. Pain and odema of patient subside soon(18). Ajeerna is the condition in which acharya charaka said that the person suffering from the disease, should not be given normal vamana drugs to induced vamana. Lukewarm saltwater is advised in this situation(19). Acharya Kashyapa has mentioned that no liquid medicines should be administered suddenly in case of amlapitta, other than the vamanoaushadha(20)

\section{Materials and Methods}

The concept of sadyovamana is studied through classical text of Ayurveda Charak Samhita, Sushrut Samhita, Ashtang hridaya, Madhava Nidana, Sharangdhara Samhita, Vangsena samhita, Bhaishajya ratnavali were studied. Along with this literature available from various search engines were also studied, then analysis of literature has been done.

\section{Result and Discussion \\ Procedure of Sadyovamana}

Criteria for sadyovamana are, utklishta dosha, atyayika avastha (emergency condition) and vamya rogi(21).To perform sadyovamana, kapha and pitta dosha must be in utklishta stage. Acharya Chakrapani has mentioned utklishta avastha means dosha are detached and ready to come out from amasaya(22). Acharya Sushruta has mentioned that when irritated food associated with salivation, spitting and does not come out but produces pain in the cardiac region it is known as utklesha(23) Vamana should be performed in the morning i.e. kapha kala. However, in atyayika vikara (when the disease in the emergency stage) there is no need to consider kala while performing any panchakarma procedure, as dosha is in utklishta stage so consideration of time does not matter many more. 
The necessity of purvakarma in sadyovamana is to mobilize the doshas from the discrete parts of the body to koshtha, for easier vamana process with minimum strain, to prevent vata prakopa and for softening and liquifying the doshas. In the case of an acute attack of a disease where sadyovamana is to be administered for instant management, it is not mandatory to do abhyanga (massage)and swedana (sudation). Purvakarma procedure of sadyovamana may vary from disease to disease. E.g. in the case of visha, ajirna, etc emergency conditions directly vamana dravya is given to remove the visha and undigested food without abhyanga and swedana. But in acute attack of shwasa, lavana taila abhyanga and swedana are essential to liquefy the kapha, bring the kapha to amashaya from pranavaha strotas thus helps in easy elimination(24).

Yavagu (rice mixed with a small quantity of ghee) should be given before sadyovamana. Vamana should not be administered to patients with an empty stomach.

\section{Pradhana Karma}

The procedure of Sadyovamana is as of classical vamana. Since there is utklistha avastha of dosha, the drug which is used in the procedure is vamanopaga like lawanambu. Different drugs can be used in different diseases as shown in table no. 1

Table no.1: Dravya used to perform Sadyovamana

\begin{tabular}{|c|c|c|c|}
\hline $\begin{array}{l}\text { Sr. } \\
\text { no. }\end{array}$ & Compendia & Disease & $\begin{array}{l}\text { Sa d y o vama } \\
\text { dravya }\end{array}$ \\
\hline 1 & Charaka & Amajwara & Lawanambu \\
\hline 2 & Charaka & Alasak & $\begin{array}{l}\text { Ushna } \\
\text { lawanambu }\end{array}$ \\
\hline 3 & Sushruta & $\begin{array}{l}\text { Pittaj } \\
\text { jwara }\end{array}$ & Lawanambu \\
\hline 4 & Sushruta & Madatyaya & $\begin{array}{l}\text { Ikshurasa, } \\
\text { Madya }\end{array}$ \\
\hline 5 & Vagbhata & Jwara & $\begin{array}{l}\text { Sura, } \\
\text { Tittira mansarasa }\end{array}$ \\
\hline 6 & Kashyapa & Amlapitta & $\begin{array}{l}\text { Law a n a m bu, } \\
\text { kshira, } \\
\text { ikshurasa }\end{array}$ \\
\hline 7 & Vangsen & Visuchika & $\begin{array}{l}\text { Ushna } \\
\text { lawanambu }\end{array}$ \\
\hline 8 & Vangsen & Visha & $\begin{array}{l}\text { Madanphala, } \\
\text { Sunthi }\end{array}$ \\
\hline 9 & $\begin{array}{l}\text { Bhaishajya } \\
\text { ratnavali }\end{array}$ & Ajirna & $\begin{array}{l}\text { Vacha, } \\
\text { lawanambu }\end{array}$ \\
\hline
\end{tabular}

\section{Pashchat karma}

After achieving samyak shuddhi lakshana patient is asked to take rest, dhumpan, and peyadi sansarjana krama (diet regimen).

\section{Mode of action of classical vamana}

According to Acharya Charaka, the emetic drug has ushna, teekshna, sukshma, vyavayi and vikasi guna. By their potency, it reaches to the heart and circulates through vessels. Because of their agneya nature, they liquify the compact doshas. Teekshna guna

separated the adhered doshas located in gross and subtle channels of the body (sthula and sukshma strotas). These separated doshas are brought to amashaya due to anupranav bhava. Doshas get stimulated by udan vayu as vamak drug have urdhwabhaghara prabhava due to agni and vayu predominance which ultimately leads to migration of doshas towards mouth from amashaya(25).

Mode of action of sadyovamana is also the same as that of classical vamana except purvakarma is not done in sadyovamana. The doshas expelled from localize tissue. The dravya use for sadyovamana is vamanopaga dravya (drug helps for vamana). Some basic difference in classical vamana and sadyovamana showing in table no. 2.

\section{Table no.2: Difference between Sadyo Vamana and Classical Vamana:}

Sr.

No.
Sadyo Vamana

Vam an $a$

c o n d u c t e d immediately in a single day.

Purva karmas like ama pachana, snehana, swedana are not mandatory to carry out Sadyovamana(26).

The doshas are

3 expelled out from localise tissue.

4 Not require vishram kala (gap period).

The person who is not co-operative, don't have much

5 time and dosha are in utklista avastha, $\mathrm{s} a d y$ ov a m a n a carried out.

6 Short-acting effect

\section{Classical Vamana}

Vamana conducted by arohana krama Sneha pana upto samyak snigdha lakshana.

Purva karmas like pachana, snehana, swedana a r e mandatory.

The doshas are expelled out from the system, i.e deep tissue.

Require vishram kala (gap period)(27).

Patients should be co-operative, have ample time to take treatment, and $\mathrm{b} h i s h a k$ vashya (obedient).

\section{Long-lasting effect.}

In sadyovamana we are not following increasing order of oletion (arohana krama snehpana) and the vishram kala etc as per the guidelines by the Acharyas. Because of these, we are not eliminating prabhuta dosha from the deeper tissue. Sadyovamana has minimal efficacy and instant relief like as ajeerna.

Sadyovamana is carried out when dosha utklishta lakshnas like hrullas, lala praseka, shiro gourava, kapha sthivana, bhakta dwesha etc are present. Purvakarma like ama pachana, snehna, swedana are not mandatory for sadyo vamana. Otherwise the dosha utklishta avastha is reduced. Sadyo vamana may be practised instantly in conditions like tamaka swasa(28)(2)(bronchial asthma), urdhwaga 
amlapitta, ajeerna etc. It can be practiced in various emergency conditions kapha utklesha avastha in disease, visha pana, ajeerna, amlapitta, and dental caries(29)as an emergency treatment.

\section{Benefits of sadyovamana}

It is cost-effective as we can perform it without snehapana. It is less time consuming as classical vamana requires a minimum of 15 days. Sadyovamana can carry out according to the situation instantly. And we can observe the immediate effect of sadyovamana as good as classical vamana.

\section{Conclusion}

Sadyovamana is an important panchakarma process which is least practiced. It is a tool that can be used in various emergency diseased conditions. It gives instant relief in utklishta doshavastha. It is a costeffective, less time consuming, and easy to carry out.

\section{References}

1. Agnivesha, Charaka, Dridhabala, Charak Samhita, Chikitsa Sthana, Jwarachikitsa Adhyay, 3/146, edited by Sharma PV, Reprint ed. Chaukhambha Orientalia, Varanasi, 2011; 67.

2. Agnivesha, Charaka, Dridhabala, Charak Samhita, Chikitsa Sthana, Hikkashwasachikitsa Adhyay, 17/85, edited by Sharma PV, Reprint ed. Chaukhambha Orientalia, Varanasi, 2011; 293.

3. Sushruta, Sushruta Samhita, Sutra Sthana, Jwarachikitsa Adhyaya, 39/180, translated by Prof. Srikantha Murthy KR. Vol. 1. Chaukhamba Orientalia, Varanasi, 2008; 203.

4. Agnivesha, Charaka, Dridhabala, Charak Samhita, Chikitsa Sthana, Hikkashwasachikitsa Adhyay, 17/45, edited by Sharma PV, Reprint ed. Chaukhambha Orientalia, Varanasi, 2011; 290.

5. Agnivesha, Charaka, Dridhabala, Charak Samhita, AyurvedaDeepika commented by Chakrapani, Chikitsa Sthana, Hikkashwaschikitsa Adhyay, 17/8, edited by Jadhavji Trikamaji Acharya, Reprint ed. Chaukhambha Surbharati Publication, Varanasi, 2009; 533.

6. Ashtang sangraha, 6/5, http://archive.org/details/ AshtangaSangraha/ 6/5/n345/mode/1up.

7. Sushruta, Sushruta Samhita, Sutra Sthana, Panatyayapratisedha Adhyaya, 47/27, translated by Prof. Srikantha Murthy KR. Vol. 3. Chaukhamba Orientalia, Varanasi, 2008; 309.

8. Agnivesha, Charaka, Dridhabala, Charak Samhita, Chikitsa Sthana, Vishachikitsa Adhyay, 23/45, edited by Sharma PV, Reprint ed. Chaukhambha Orientalia, Varanasi, 2011; 369.

9. Agnivesha, Charaka, Dridhabala, Charak Samhita, AyurvedaDeepika commented by Chakrapani, Chikitsa Sthana, Vishachikitsa Adhyay, 23/238, edited by Jadhavji Trikamaji Acharya, Reprint ed. Chaukhambha Surbharati Publication, Varanasi, 2009; 581 .

10. Madhav nidan, Madhukosha Vyakhya, Chhardi nidan, 4, translated by Yadunandan Upadhyay Part
2, Reprint ed Chaukhamba Publication, Varanasi, 2017; 346.

11. Madhav nidan, Madhukosha Vyakhya, Kotha nidan, 50/4, translated by Yadunandan Upadhyay Part 2, Reprint ed Chaukhamba Publication, Varanasi, 2017; 202.

12. Vangasen, Vangasen Samhita, Udarda-SheetpittaKotha Adhikar, 26/7, edited by Pandit Tripathi Hariprasad, Chaukhamba Sanskrit Series publication, Varanasi, 2016; 354.

13. Agnivesha, Charaka, Dridhabala, Charak Samhita, Viman Sthana, Trividhkukshiya Adhyay, 2/13, edited by Sharma PV, Reprint ed. Chaukhambha Orientalia, Varanasi, 2011; 312.

14. Madhav nidan, Madhukosha Vyakhya, Visuchika nidan, 2/16, translated by Yadunandan Upadhyay Part 1, Reprint ed Chaukhamba Publication, Varanasi, 2017; 231.

15. Vangasen, Vangasen Samhita, Visuchika Adhikar, 39/160, edited by Pandit Tripathi Hariprasad, Chaukhamba Sanskrit Series publication, Varanasi, 2016; 529.

16. Agnivesha, Charaka, Dridhabala, Charak Samhita, Siddhi Sthana, Vamanvirechanavyapadsiddhi Adhyay, 6/21, edited by Sharma PV, Reprint ed. Chaukhambha Orientalia, Varanasi, 2011; 625.

17. Sushruta, Sushruta Samhita, Chikitsa Sthana, Vamanvirechanavyapacchikitsitam Adhyaya, 34/6, translated by Prof. Srikantha Murthy KR. Vol. 1. Chaukhamba Orientalia, Varanasi, 2008; 320.

18. Vangasen, Vangasen Samhita, Upadamsharoga Adhikar, 23/8-9, edited by Pandit Tripathi Hariprasad, Chaukhamba Sanskrit Series publication, Varanasi, 2016; 318.

19. Agnivesha, Charaka, Dridhabala, Charak Samhita, Siddhi Sthana, Vamanvirechanvyapadsiddhi Adhyay, 6/14, edited by Sharma PV, Reprint ed. Chaukhambha Orientalia, Varanasi, 2011; 624.

20. Vriddhajivaka, Kashyapa, Kashyapa Samhita, Khilasthana, Amlapittachikitsa adhyaya, 16/22, edited by Sharma Hemraj, Reprint Eighth edition, Chaukhamba Sanskrit Sansthan, Varanasi, 2008; 337.

21. Agnivesha, Charaka, Dridhabala, Charak Samhita, Siddhi Sthana, Panchakarma siddhi Adhyay, 2/10, edited by Sharma PV, Reprint ed. Chaukhambha Orientalia, Varanasi, 2011; 598.

22. Agnivesha, Charaka, Dridhabala, Charak Samhita, AyurvedaDeepika commented by Chakrapani, Chikitsa Sthana, Jwarachikitsa Adhyay, 3/146, edited by Jadhavji Trikamaji Acharya, Reprint ed. Chaukhambha Surbharati Publication, Varanasi, 2009; 410.

23. Sushruta, Sushruta Samhita, Uttartantra Sthana, Jwarapratisedha Adhyaya, 39/101, translated by Prof. Srikantha Murthy KR. Vol. 1. Chaukhamba Orientalia, Varanasi, 2008; 191.

24. Agnivesha, Charaka, Dridhabala, Charak Samhita, Chikitsa Sthana, Hikkashwasachikitsa Adhyay, 17/71,75, edited by Sharma PV, Reprint ed. Chaukhambha Orientalia, Varanasi, 2011; 292. 
25. Agnivesha, Charaka, Dridhabala, Charak Samhita, Kalpa Sthana, Madankalpadhyay Adhyay, 1/5, edited by Sharma PV, Reprint ed. Chaukhambha Orientalia, Varanasi, 2011; 537.

26. Agnivesha, Charaka, Dridhabala, Charak Samhita, AyurvedaDeepika commented by Chakrapani, Chikitsa Sthana, Jwarachikitsa Adhyay, 3/146, edited by Jadhavji Trikamaji Acharya, Reprint ed. Chaukhambha Surbharati Publication, Varanasi, 2009; 410 .

27. Agnivesha, Charaka, Dridhabala, Charak Samhita, Sutra Sthana, Upakalpaniya Adhyay, 15/14, edited by Sharma PV, Reprint ed. Chaukhambha Orientalia, Varanasi, 2011; 107.

28. Ghansham N. Jadhav et al: Sadyo Vaman In Tamaka Shwas an Atyayik Chikitsa: A Case Report. International Ayurvedic Medical Journal \{online\} 2019 \{cited February, 2019\} Available from: http:// www.iamj.in/posts/images/upload/282_285.pdf

29. Vijayalakshmi N. Role of Sadyo Vamana in dental abscess (danta arbuda). Ancient Sci Life 2012;32:104-6. 